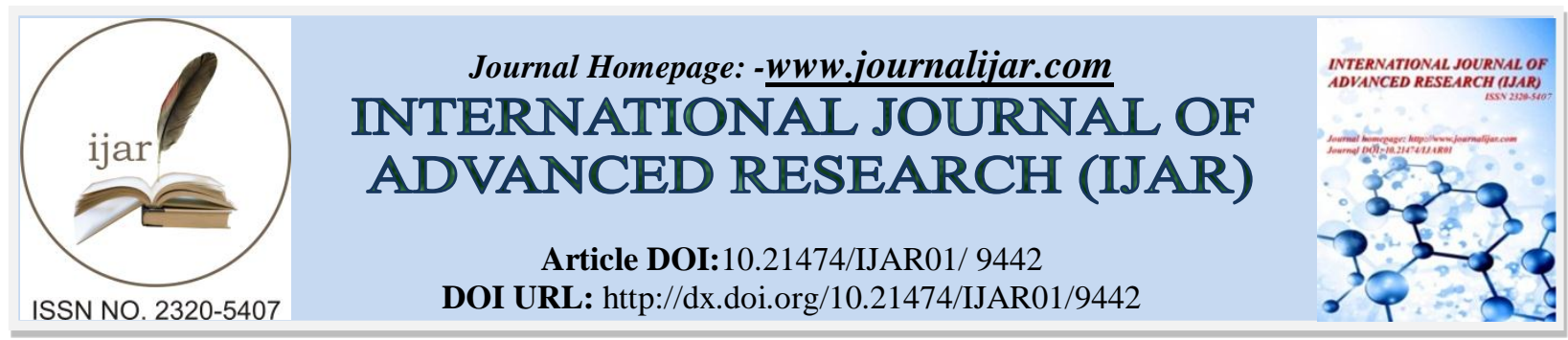

RESEARCH ARTICLE

\title{
LAPAROSCOPY AS A SUITABLE AND SAFE ALTERNATIVE TO OPEN SURGERY IN MANAGEMENT OF PERFORATED PEPTIC ULCER: A COMPARATIVE STUDY.
}

Waleed A. Abd-Elhady and Loay M. Gertallah.

General Surgery department, Faculty of Medicine, Zagazig University.

\section{Manuscript Info}

Manuscript History

Received: 24 May 2019

Final Accepted: 26 June 2019

Published: July 2019

Key words:-

perforated peptic ulcer; laparoscopy, open technique.

\begin{abstract}
Background: Laparoscopic surgeries become the gold standard procedure of management of many elective surgical problems, but its role in acute emergent surgical problems as in perforated peptic ulcer (PPU) management has been still controversial and needs further evaluation.

The aim of the present study was to compare between laparoscopic repair and open repair for the surgical management of PPU to give an evidence-based clue for selecting most appropriate surgical management technique.

Patients and Methods: in the current study we included 30 patients which were divided into 2 groups; group 1 included 15 patients where we managed them by laparoscopic simple closure of the perforation with an omental patch and group 2 included 15 patients where we performed simple closure of the perforation with an omental patch through open surgery.

Results: There is statistically significant association between both groups regarding duration of hospital stay (days), presence of surgical site infection, postoperative morbidity $(\mathrm{p}<0.001)$, postoperative mortality $(\mathrm{p}=0.009)$ (more in the open group), clinical cure without complication (less in the open group) $(\mathrm{p}=0.002)$.

Conclusions: Our study clarified the benefits of laparoscopic repair of PPU than open surgical repair of PPU regarding less postoperative pain, infection, morbidities, mortality and shorter duration of hospitalization in comparison with open repair.
\end{abstract}

Copy Right, IJAR, 2019,. All rights reserved.

\section{Introduction:-}

Before the $20^{\text {th }}$ century, perforated peptic ulcer (PPU) was a fatal and rare surgical problem that has steadily increased incidence, mainly in elderly population [1].

The usual treatment of PPU is its surgical repair after laparotomy using variable surgical techniques [2]. Minimally invasive surgical procedures have been significantly improved since the 20th century beginning due to improvement of materials, optics, manufacturing, in addition to the increasing experience of surgeons to the surgical technique. Laparoscopic surgeries have become the gold standard managing procedure of many elective surgical problems, but its role in acute emergent surgical problems as in the PPU management has been still controversial and needs further

Corresponding Author:-Waleed A. Abd-Elhady.

Address:-General Surgery department, Faculty of Medicine, Zagazig University. 
evaluation [2]. Laparoscopic repair of PPU was first reported in year 1990 [3]. Since then there are much debate regarding its benefits. Although most previous studies showed that it was a feasible and easily performed procedure, but it has no significant benefits [4]. There are no conclusive studies regarding the benefits of laparoscopic management of PPU and its drawbacks like; longer operative time, occurrence of post-operative pain, leakage, wound infection and overall mortality $[2,5]$. So, there is a low incidence of accepting laparoscopy as a preferred management method of PPU.

The aim of the present study was to compare between laparoscopic repair and open repair for the surgical management of PPU to give an evidence-based clue for selecting most appropriate surgical management technique.

\section{Patients And Methods:-}

The present study is a prospective cohort study which was performed in General Surgery Department, Zagazig University Hospitals, Faculty of Medicine, and Internal Medicine Department, Faculty of Medicine, Zagazig University in the period from June 2017 to June 2019.

We have included thirty patients with PPU who were diagnosed by history, clinical examination and by radiological evaluation. The studied patients were divided into 2 groups; group 1 included 15 patients where we managed them by laparoscopic simple closure of the perforation with an omental patch and group 2 included 15 patients where we performed simple closure of the perforation with an omental patch through open surgery. We assessed intraoperative and peri-operative parameters to allow making adequate comparison between both techniques, and then we followed-up our patients by performing upper gastrointestinal (GIT) endoscopy in Gastroenterology and Hepatology unit Internal Medicine Department, Faculty of medicine, Zagazig University to detect post-operative patients outcome, recovery and complication.

\section{Inclusion criteria}

\section{Patients with PPU were included in the study.}

All patients who have undergone open or laparoscopic repair of PPU by closure with omental patch in Zagazig university hospitals between June 2017 and June 2019 were prospectively included in the present after obtaining approval from the local ethical committee of faculty of medicine Zagazig University. We assessed and analyzed patients' demographic data, comorbidities, operative data, postoperative complications and outcomes.

\section{Exclusion criteria}

We have excluded; patients with previous history of upper abdominal surgery, clinical evidence of bleeding ulcer, presence of obstruction of the gastric outlet, large and malignant ulcers. Deciding which technique will be used for PPU repair depends on the presence of qualified trained surgeons having adequate laparoscopic experience. Laparoscopic repair was done using intra-corporeal suturing and closure with omental patch while we performed the open repair via a midline laparotomy then closure with a pedicled omental patch. We have resuscitated all included patients before surgery with isotonic crystalloids, adequate analgesia, intravenous broad spectrum antibiotics and a dose of intravenous proton-pump inhibitor (PPI). We performed nasogastric decompression to decrease amount of peritoneal spillage and the risk of aspiration. We put a Foley's bladder catheter to assess urine output and to evaluate the degree of fluid resuscitation. We have taken blood samples from all studied patients then tested them for full blood counts, electrolyte panel and serum amylase. Diagnosis of PPU was done by an erect chest radiograph that revealed the presence of air under diaphragm, if there were any doubts we required a computed tomography scan to confirm the diagnosis.

\section{Surgical Technique \\ Management of patients in the first group by laparoscopic repair of PPU:}

We have placed the patients supine on the operating table with their arms out. We used the open technique to get into the abdomen and put the $1^{\text {st }} 10$-mm port in peri-umbilical region in the midline. We have used a $30^{\circ}$ camera for inspection of the abdomen. As we are the operating surgeons we stood between the patients's legs, and inserted 2 a 5 -mm ports in the left and right upper quadrants in mid-clavicular area at about a hand breadth below the costal margin. If we needed retraction we inserted a 5-mm port in the right upper quadrant in the anterior axillary line and then grasped the gallbladder towards the right shoulder tip. Once we identified the perforation we sutured a piece of the omentum on the perforation site using 2.00-3.00 Vicryl sutures. If we cannot identify the perforation site clearly identified, we performed an intraoperative endoscopy. We washed the abdomen in all patients using 4,000-6,000 $\mathrm{mL}$ saline until the abdominal cavity was clean. We inserted drains for all patients. We closed the 10-mm port fascia 
with a Vicryl 0 suture. We removed the drains once the patients tolerated a normal diet without bilious output from the drain.

\section{Surgical management of group 2}

We performed the surgical procedure of the open repair of PPU through upper midline laparotomy. We performed gastroscopy for patients about 6-8 weeks after surgery to detect the presence of $H$. pyloi. We performed repair of PPU with omental patch as described by Winslet MC [6].

Oral intake was done after returning of bowel function, at about 24 hours after surgery.

Patients that underwent open repair of PPU received strong analgesic, morphine, immediately at the postoperative period. We give the patients a single dose of PPI intravenously twice daily, in addition to intravenous cefoperazone and metronidazole for the first 2-3 days. We stop doses of intravenous PPI therapy once patients could be able to tolerate oral therapy, and replaced the by oral PPI, clarithromycin, and amoxicillin twice daily for 1 week for eradication of $\mathrm{H}$ pylori infection, followed by oral PPI once daily for 5 weeks.

We performed upper gastrointestinal endoscopy within 6 weeks post-operatively to evaluate degree of healing of the ulcer and to have several biopsies to exclude malignancy and $\mathrm{H}$ pylori infection.

Follow-up of patients in the post-operative period is done to detect postoperative complications that were related to the PPU or the surgery performed as respiratory complications, cardiac complications, intra-abdominal collection, surgical site infection, ileus, and even death.

\section{Statistical Analysis}

We made analysis of data analysis by the software SPSS (Statistical Package for the Social Sciences) program version 20, described quantitative data by using means and standard deviations compared them by using Chi square test and used the independent sample $t$ test to compare the means of both groups of the included patients. Used the significant value of $(P<0.05)$.

\section{Results:-}

Our study included 30 patients with PPU which were managed over 2 years. Their age ranged from 20 to 51 years Mean \pm SD $=36.1 \pm 8.88$ years. There were $27(90 \%)$ male patients and $3(10 \%)$ female patients no significant association between both groups of patients regarding age or sex of patients. We have performed laparoscopic repair of PPU in 15 patients while the remaining 15patients have undergone open repair of PPU.

There were no statistically significant relations between both included groups of patients regarding past history of smoking, alcoholism, clinical presentation, duration of symptoms, presence of pre-operative shock, co-morbid conditions, duration of perforation, site or size of the perforation and operating time.

There is statistically significant association between both groups regarding duration of hospital stay (days), presence of surgical site infection, postoperative morbidity $(\mathrm{p}<0.001)$, postoperative mortality $(\mathrm{p}=0.009)$ (more in the open group), clinical cure without complication (less in the open group) ( $\mathrm{p}=0.002)$.

Table 1:-Comparison between laparoscopic repair and open repair in management of perforated peptic ulcer regarding demographic and pre-operative data:

\begin{tabular}{|c|c|c|c|c|}
\hline \multirow[t]{3}{*}{ Variables } & \multirow{3}{*}{$\begin{array}{l}\text { Total } \\
\mathrm{N}=30(\%) \\
\end{array}$} & \multicolumn{2}{|l|}{ Surgical techniques } & \multirow{3}{*}{$\mathrm{p}$} \\
\hline & & Laparoscopic repair & Open repair & \\
\hline & & $\mathrm{N}=15(50 \%)$ & $\mathrm{N}=15(50 \%)$ & \\
\hline $\begin{array}{l}\text { Age (years): } \\
\text { Mean } \pm \text { SD } \\
\text { Range }\end{array}$ & $\begin{array}{l}36.1 \pm 8.88 \\
20-51\end{array}$ & $\begin{array}{l}42 \pm 5.84 \\
34-51\end{array}$ & $\begin{array}{l}30.2 \pm 7.38 \\
20-45\end{array}$ & $<0.001 * *$ \\
\hline $\begin{array}{l}\text { Gender: } \\
\text { Male } \\
\text { Female }\end{array}$ & $\begin{array}{l}27(90) \\
3(10)\end{array}$ & $\begin{array}{l}13(86.7) \\
2(13.3)\end{array}$ & $\begin{array}{l}14(93.3) \\
1(6.7)\end{array}$ & 1 \\
\hline Smoking: & & & & \\
\hline
\end{tabular}




\begin{tabular}{|l|l|l|l|l|}
\hline Absent & $15(50)$ & $10(66.7)$ & $5(33.3)$ & 0.143 \\
Present & $15(50)$ & $5(33.3)$ & $10(66.7)$ & \\
\hline $\begin{array}{l}\text { Alcoholism: } \\
\text { Absent }\end{array}$ & $24(80)$ & $13(54.2)$ & $11(45.88)$ & \\
Present & $6(20)$ & $2(33.3)$ & $4(66.7)$ & 0.651 \\
\hline $\begin{array}{l}\text { Comorbid condition: } \\
\text { Absent }\end{array}$ & $20(66.7)$ & $8(40)$ & $12(60)$ & \\
Present & $10(33.3)$ & $7(70)$ & $3(30)$ & 0.245 \\
\hline $\begin{array}{l}\text { Clinical presentation: } \\
\text { Severe abdominal pain and }\end{array}$ & & & & \\
distension & $8(26.7)$ & $3(37.5)$ & $5(62.5)$ & \\
$\begin{array}{l}\text { Nausea, vomiting, dyspepsia } \\
\text { Fever and shock }\end{array}$ & $11(36.7)$ & $4(36.4)$ & $7(63.6)$ & \\
Classical signs of peritonitis & $6(16.7)$ & $3(60)$ & $2(40)$ & \\
\hline $\begin{array}{l}\text { Preoperative shock: } \\
\text { Absent }\end{array}$ & $19(63.3)$ & $7(36.8)$ & $12(63.7)$ & \\
Present & $11(36.7)$ & $8(62.7)$ & $3(27.3)$ & \\
\hline $\begin{array}{l}\text { Duration of perforation: } \\
\text { <24 hours }\end{array}$ & $14(46.7)$ & $7(36.8)$ & $7(36.8)$ & \\
$>24$ hours & $16(53.3)$ & $8(62.7)$ & $8(62.7)$ & \\
\hline
\end{tabular}

${ }^{* *} \mathrm{p} \leq 0.001$ is statistically highly significant ${ }^{*} \mathrm{p}<0.05$ is statistically significant $\quad \mathrm{t}$ independent sample $\mathrm{t}$ test

Table 2:-Comparison between laparoscopic repair and open repair in management of perforated peptic ulcer regarding operative and postoperative data:

\begin{tabular}{|c|c|c|c|c|}
\hline \multirow[t]{3}{*}{ Variables } & \multirow{3}{*}{$\begin{array}{l}\text { Total } \\
\mathbf{N}=30(\%) \\
\end{array}$} & \multicolumn{2}{|c|}{ Surgical techniques } & \multirow{3}{*}{$\mathrm{p}$} \\
\hline & & $\begin{array}{l}\text { Laparoscopic } \\
\text { repair }\end{array}$ & Open repair & \\
\hline & & $\mathrm{N}=15(\%)$ & $\mathrm{N}=15(\%)$ & \\
\hline $\begin{array}{l}\text { Size of ulcer }(\mathbf{c m}): \\
<3 \mathrm{~cm} \\
\geq 3 \mathrm{~cm}\end{array}$ & $\begin{array}{l}28(6.7) \\
2(93.3)\end{array}$ & $\begin{array}{l}15(53.6) \\
0(0)\end{array}$ & $\begin{array}{l}13(46.4) \\
2(100)\end{array}$ & 0.483 \\
\hline $\begin{array}{l}\text { Site of ulcer: } \\
\text { Prepyloric } \\
\text { Lesser curvature } \\
\text { Antrum } \\
\text { Greater curvature }\end{array}$ & $\begin{array}{l}19(63.3) \\
4(13.3) \\
4(13.3) \\
3(10)\end{array}$ & $\begin{array}{l}10(52.6) \\
2(50) \\
2(50) \\
1(33.3)\end{array}$ & $\begin{array}{l}9(47.4) \\
2(50) \\
2(50) \\
2(66.7)\end{array}$ & 0.943 \\
\hline $\begin{array}{l}\text { Duration of operation } \\
\text { (hours): } \\
\text { Mean } \pm \text { SD } \\
\text { Range }\end{array}$ & $\begin{array}{l}1.47 \pm 0.45 \\
1-1.5\end{array}$ & $\begin{array}{l}1.07 \pm 0.18 \\
1.3-1.5\end{array}$ & $\begin{array}{l}1.17 \pm 0.13 \\
1-1.3\end{array}$ & 1 \\
\hline $\begin{array}{l}\text { Duration of hospital stay } \\
\text { (days): } \\
\text { Mean } \pm \text { SD } \\
\text { Range }\end{array}$ & $\begin{array}{l}7.37 \pm 1.5 \\
5-10\end{array}$ & $\begin{array}{l}5.2 \pm 0.86 \\
5-6\end{array}$ & $\begin{array}{l}9.53 \pm 0.99 \\
9-10\end{array}$ & $<0.001 * *$ \\
\hline $\begin{array}{l}\text { Postoperative leakage: } \\
\text { Absent } \\
\text { Present }\end{array}$ & $\begin{array}{l}23(76.7) \\
7(23.3)\end{array}$ & $\begin{array}{l}11(47.8) \\
4(57.1)\end{array}$ & $\begin{array}{l}12(52.2) \\
3(42.9)\end{array}$ & 1 \\
\hline $\begin{array}{l}\text { Surgical site infection: } \\
\text { Absent } \\
\text { Present }\end{array}$ & $\begin{array}{l}18(60) \\
12(40)\end{array}$ & $\begin{array}{l}14(93.3) \\
1(6.7)\end{array}$ & $\begin{array}{l}4(20) \\
11(80)\end{array}$ & $<0.001 * *$ \\
\hline $\begin{array}{l}\text { Postoperative morbidity: } \\
\text { Absent } \\
\text { Present }\end{array}$ & $\begin{array}{l}18(60) \\
12(40)\end{array}$ & $\begin{array}{l}14(93.3) \\
1(6.7)\end{array}$ & $\begin{array}{l}4(20) \\
11(80)\end{array}$ & $<0.001 * *$ \\
\hline Postoperative mortality: & & & & \\
\hline
\end{tabular}




\begin{tabular}{|l|l|l|l|l|}
\hline $\begin{array}{l}\text { Absent } \\
\text { Present }\end{array}$ & $\begin{array}{l}25(83.3) \\
5(16.7)\end{array}$ & $\begin{array}{l}14(93.3) \\
1(6.7)\end{array}$ & $\begin{array}{l}11(80) \\
4(20)\end{array}$ & 0.009 \\
\hline $\begin{array}{l}\text { Clinical cure without } \\
\text { complication: }\end{array}$ & & & & \\
Absent & $10(33.3)$ & $1(6.7)$ & $9(45)$ & 0.002 \\
Present & $20(66.7)$ & $14(93.3)$ & $6(45)$ & \\
\hline
\end{tabular}

$* * p \leq 0.001$ is statistically highly significant $* p<0.05$ is statistically significant $t$ independent sample $t$ test

\section{Discussion:-}

Laparoscopic surgery has been increasingly used in several aspects of emergent gastrointestinal surgeries; it has many benefits as decreasing post-operative morbidity, cost, pain and mortalityin addition to an earlier return to work with resumption of normal daily activities [8-10]. In the current study we showed that laparoscopic repair of PPU is better than open repair of such surgical problem with a significant decrease in postoperative morbidity, pain, wound infection and rabid recovery. Similarly, the results of Quah et al. [1], in their meta-analysis, and results of Li et al., [2].

Our results support the possibility of routine using laparoscopy in repair of PPU. in the early 1990s laparoscopic surgical techniques role in emergency surgeries was controversial due to the possible risks of bacteraemia or even toxaemia in the presence of abdominal sepsis, mostly due to performing carbon dioxide pneumo-peritoneum and the increased in intra-abdominal pressure. But previous studies which assessed the benefits of using laparoscopic management of generalized peritonitis disproved that past theory [11]. In the present study we demonstrated no significant differences in the occurrence of sepsis or increasing incidence of leakage or intra-abdominal collections in laparoscopic repair than open repair of PPU, this was nearly similar to Quah et al. [1] the rate of leakage occurrence was markedly lower than that showed in previous studies [12]. The reduction in rates of leakage is due to improved laparoscopic techniques, equipment and laparoscopic surgical experiences. Ukai et al., [13], meta-analysis showed marked reduction in the postoperative morbidity for emergency laparoscopic surgeries. The previously discovered disadvantage of laparoscopic repair of PPU was the longer operating time but due to increasing the laparoscopic expertise and novel techniques, we found no statistically significant differences between open and laparoscopic repair. We found similar results to Quah et al. [1], meta-analysis who provided an obvious evidence that laparoscopic repair is a safe method that could be safely used in treating PPU when compared with the open repair. Moreover, we found that there was increased risk of post-operative leakage or sepsis. Mirabella et al., [14], results showed that laparoscopic repair of PPU could be a safe alternative to open surgery which proved our findings. Laparoscopic repair has many advantages over open repair with early oral food intake, shorter duration of hospital stay, lower incidence of wound infections in adition to general reduction in postoperative morbidity and mortality [15]. Many previous studies proved the safety and several advantages of laparoscopy over open surgery [16]. Although using laparoscopy was proposed by Lagoo et al., [17] in 1992 to be used routinely in management of PPU but, up-till, open surgery is still a method of choice for PPU repair although the laparoscopic repair is safe and have many benefits due to many factors (1) the low incidence of PPU that lead to reduction in rate of exposure to cases that need surgical intervention (2) absence of well qualified surgeons on-duty all the time in hospitals for treatment of PPU patients (3) absence of laparoscopic experience of the surgeon could result in a high rate of conversion to open surgery. The main advantage of laparoscopic repair is reduction of surgical site infection which is a major complication of PPU repair through open surgery; this is because of reduction of the size of the incision, lesser injury to tissue, less immune or inflammatory responses [12, 18]. Biscione et al., [19], showed that laparoscopic repair reduce the incidence of surgical site infection, and our study showed similar outcomes. moreoved the increased cost which is attributed to the longer operating time in laparoscopic repair is compensated by the shorter duration of hospital stay. Similarly, several studies demonstrated reduction in duration of hospital stay in laparoscopic repair of PPU than in open repair from 10.3 days to 6.3 days [12]. Jamal et al., [20], showed that at centers which used laparoscopy as a routine management method for PPU, there were better outcomes in comparison to open technique.

\section{Summary and Conclusion:-}

Our study clarified the benefits of laparoscopic repair of PPU than open surgical repair of PPU regarding less postoperative pain, infection, morbidities, mortality and shorter duration of hospitalization in comparison with open repair. Moreover we showed that using laparoscopy in the treatment of PPU is a safe and feasible method which is associated with better outcomes even in patients with associated comorbidities. Although the using the laparoscopic 
approach in repair of PPU have many advantages over open surgical repair regarding postoperative morbidities and mortality, but detailed studies are needed to clarify these advantages. Additional randomized trials are needed to analyze the efficacy of laparoscopy over open technique in management of PPU.

\section{References:-}

1. Quah GS, Eslick GD, Cox MR. Laparoscopic Repair for Perforated Peptic Ulcer Disease Has Better Outcomes Than Open Repair Journal of Gastrointestinal Surgery (2019) 23:618-625

2. Siow SL, Mahendran HA, Wong CM, Hardin M, Luk TL. Laparoscopic versus open repair of perforated peptic ulcer: Improving outcomes utilizing a standardized technique Asian Journal of Surgery (2018) 41, 136e142

3. Mouret P, Francois Y, Vignal J, Barth X, Lombard-Platet R. Laparoscopic treatment of perforated peptic ulcer. Br J Surg. 1990; 77(9):1006.

4. Sanabria A, Villegas MI, Morales Uribe CH. Laparoscopic repair for perforated peptic ulcer disease. Cochrane Database of Syst Rev. 2013; 2:CD004778.

5. Zhou C, Wang W, Wang J, Zhang X, Zhang Q, Li B, et al. An Updated Meta-Analysis of Laparoscopic Versus Open Repair for Perforated Peptic Ulcer. Sci Rep. 2015; 5:13976.

6. Winslet MC. Stomach and duodenum. In: Kirk RM, ed. General surgical operations. London: Churchill Livingston; 2007:174e177.

7. Cellan-Jones CJ. A rapid method of treatment in perforated duodenal ulcer. Br Med J. 1929;1:1076e1077.

8. Jimenez Rodriguez RM, Segura-Sampedro JJ, Flores-Cortes M, Lopez-Bernal F, Martin C, Diaz VP, et al. Laparoscopic approach in gastrointestinal emergencies. World J Gastroenterol. 2016; 22(9): 2701-10.

9. Coccolini F, Catena F, Pisano M, Gheza F, Fagiuoli S, Di Saverio S, et al. Open versus laparoscopic cholecystectomy in acute cholecystitis. Systematic review and meta-analysis. Int J Surg. 2015; 18:196-204.

10. Mandrioli M, Inaba K, Piccinini A, Biscardi A, Sartelli M, Agresta F, et al. Advances in laparoscopy for acute care surgery and trauma. World J Gastroenterol. 2016;22(2):668-80.

11. Navez B, Navez J. Laparoscopy in the acute abdomen. Best Pract Res Clin Gastroenterol. 2014;28(1):3-17.

12. Bertleff MJ, Lange JF. Laparoscopic correction of perforated peptic ulcer: first choice? A review of literature. Surg Endosc. 2010; 24(6): 1231-9.

13. Ukai T, Shikata S, Takeda H, Dawes L, Noguchi Y, Nakayama T, et al. Evidence of surgical outcomes fluctuates over time: results from a cumulative meta-analysis of laparoscopic versus open appendectomy for acute appendicitis. BMC Gastroenterol. 2016; 16: 37.

14. Mirabella A, Fiorentini T, Tutino R, Falco N, Fontana T, Marco PD, Et al., Laparoscopy is an available alternative to open surgery in the treatment of perforated peptic ulcers: a retrospective multicenter study Mirabella et al. BMC Surgery (2018) 18:78

15. Zhou C, Wang W, Wang J, Zhang X, Zhang Q, Li B, Xu Z. An Updated Meta-Analysis of Laparoscopic Versus Open Repair for Perforated Peptic Ulcer Scientific Reports 2015

16. Domı'nguez-Vega G, Pera M, Ramo' n JM, Puig S, Membrilla E, Sancho J, Grande L. Comparison of Laparoscopic Versus Open Repair for the Surgical Treatment of Perforated Peptic Ulcers Ciresp 2013 ;9 9 ( 6 ): $372-37$.

17. Lagoo S, McMahon RL, Kakihara M, Pappas TN, Eubanks S. The sixth decision regarding perforated duodenal ulcer. JSLS. 2002; 6:359e368.

18. Lau H. Laparoscopic repair of perforated peptic ulcer: a meta-analysis. Surg Endosc. 2004; 18:1013e1021.

19. Biscione FM, Couto RC, Pedrosa TM, Neto MC. Factors influencing the risk of surgical site infection following diagnostic exploration of the abdominal cavity. J Infect. 2007; 55:317e323.

20. Jamal MH, Karam A. Alsharqawi N, Buhamra A, AlBader I, Al-Abbad, Dashti M, Abulhasan YB, Almahmeed H, AlSabah S, Laparoscopy in Acute Care Surgery: Repair of Perforated Duodenal Ulcer Med Princ Pract 2019. 